\title{
Haematology and Leucocytozoonosis of Great Tits (Parus major L.) During Winter
}

\author{
K. HAUPTMANOVÁ, I. LITERÁK, E. BÁRTOVÁ \\ Department of Biology and Wildlife Diseases, Faculty of Veterinary Hygiene and Ecology, \\ University of Veterinary and Pharmaceutical Sciences, Brno, Czech Republic
}

Received December 6, 2001

Accepted June 19, 2002

\section{Abstract}

Hauptmanová K., I. Literák, E. Bártová: Haematology and Leucocytozoonosis of Great Tits (Parus major L.) During Winter. Acta Vet Brno 2002, 71: 199-204.

Only a few studies about partial haematological examination of great tits have been published so far. We performed a haematological examination of 81 great tits (Parus major) from Brno, Czech Republic, in winter 2000/2001. The examination of 80 healthy birds yielded the following results: $5.89 \pm 1.36 \times 10^{6} / \mu 1$ erythrocytes, haemoglobin content $173.2 \pm 29.9 \mathrm{~g} / \mathrm{l}$, packed cells volume $45 \pm 4$ $\%$, and $4.06 \pm 2.40 \times 10^{3} / \mu$ leucocytes $(68.5 \%$ lymphocytes, $19.6 \%$ heterophils, $5.6 \%$ eosinophils, $5.6 \%$ basophils and $1.0 \%$ monocytes). In the blood of an injured great tit having its leg amputated, we found anaemia and leucocytosis. The blood smears were tested also for the incidence of blood parasites. In three healthy birds $(3.9 \%, \mathrm{n}=77)$ we distinguished the blood parasites of Leucocytozoon genus and in one case $(1.3 \%, n=77)$ also some microfilariae (in all cases 1 parasite per $10^{5}$ erythrocytes). The injured great tit suffered from the infection with blood parasite Leucocytozoon dubreuili. We assume that the enfeeblement of organism by the trauma resulted in immunity decrease allowing the reactivation of latent infection $L$. dubreuili.

Parus major, body weight, Leucocytozoon dubreuili, total red blood cells, RBC, total while blood cells, WBC

Only a few studies of complex haematological examination of wild small passerines have been published so far (Prinzinger and Misovic 1994). Great tit (Parus major) belongs to very common wild passerines of Europe and is often used for the purposes of various environmental studies. Surprisingly, no complex haematological examination of great tits has been performed yet. Packed cells volume examination in adult great tits served as a criterion of their physical condition (Ots et al. 1998). Most of other haematological studies on tits (Parus spp.) have focused on blood smear examination when diagnosing various blood parasitoses (Garvin et al. 1993; Merino et al. 1997; Hõrak et al. 1998; Ots et al. 1998; Merino et al. 2000).

Our work concentrated on complex haematological examination of great tits in winter. We tried to found out the relationship between the haematological parameters and great tits' health condition, body weight and sex. During the examination we found Leucocytozoon parasites. One bird suffered from an acute leucocytozoonosis that was in our opinion connected with posttraumatic condition of this individual. Therefore, our work analyses also the incidence of blood parasites of Leucocytozoon genus in great tits in winter.

\section{Materials and Methods}

We were feeding, trapping and ringing small birds in the municipal park in Brno, Czech Republic. Great tit was a dominant species.

From the beginning of December 2000 to the end of February 2001 we took $50-200 \mu 1$ blood samples of 81 great tits from vena ulnaris cutanea on heparin (Heparin, Léčiva a. s., Prague, Czech Republic). We made a blood smear from one drop of non-heparinised blood. After we had determined great tits' body weight and examined their health condition by inspection, we banded them and released them. We did not use any values in this study that were obtained from the birds being trapped repeatedly.

Address for correspondence:

MVDr. Katefiina Hauptmanová

Department of Biology and Wildlife Diseases

Republic
Phone: +420541562585

Fax: + 420549243020

http://www.vfu.cz/acta-vet/actavethtm 
We determined the total red blood cells, total while blood cells, packed cell volume and haemoglobin content. We also determined the differential count of white blood cells by the examination of blood smear. On the basis of the values of packed cell volume, the total red blood cells and haemoglobin content, we calculated MCV (mean corpuscular volume), $\mathrm{MCH}$ (mean corpuscular haemoglobin) and MCHC (mean corpuscular haemoglobin concentration) (Campbell 1994). The numbers of red and white blood cells were calculated in Bürker's hemacytometer counting chamber while mixed with Natt-Herrick solution in the ratio of 1 to 200 (Natt and Herrick 1952). Packed cell volume was determined after centrifugation in haematocrit capillaries. Haemoglobin content was determined by spectrophotometry $(540 \mathrm{~nm})$ after the blood was mixed with Drabkin solution in the ratio of 1 to 250 (Drabkin 1945). Blood smears were stained with May-Grünwald and Giemsa-Romanowsky stains (Lucas and Jamroz 1961). One hundred white blood cells were evaluated in each smear. The type of blood cells was determined according to Lucas and Jamroz (1961).

We calculated mean value and standard deviation for each acquired value. The differences between males and females were compared by Student's $t$-test. The relationship between haematological parameters and birds' body weight was evaluated by correlation in males and females separately and also in all birds together (irrespective of their sex).

We monitored the incidence of parasites (Leucocytozoon spp., Trypanosoma spp., microfilariae) in blood smears. We checked at least $10^{5}$ red blood cells under 400-fold magnification (Garvin et al. 1993). Parasites genus and species were identified according to Valkiũnas (1997). We did not specify the species of the microfilariae. In the event that we distinguished the only one parasite belonging to Leucocytozoon genus, we did not specify its species. In fact, we could perform a specific morphological determination only in the one great tit because it had a greater number of Leucocytozoon parasites in its blood smear.

\section{Results}

During the monitoring period we collected blood samples of 81 great tits (42 males and 39 females).

Eighty birds were in good health condition. We observed no ectoparasites, feather or skin changes, emaciation or any injuries. The average body weight of the great tits $(n=48)$ was $17.5 \pm 1.0 \mathrm{~g}$. The males $(\mathrm{n}=23$, the average body weight $17.9 \pm 0.9 \mathrm{~g})$ showed statistically significant higher body weight ( $\mathrm{t}$-test, $p<0.01)$ as compared to the females $(\mathrm{n}=25,17.1 \pm$ $1.0 \mathrm{~g}$ ). The blood count results of both females and males are stated in Table 1.

Table 1

The results of haematological examination of great tit (Parus major) in winter

\begin{tabular}{|l|c|c|}
\hline & A & Mean \pm SD \\
\hline Red blood cells $\left(\mathrm{x} 10^{6} / \mu \mathrm{l}\right)$ & 80 & $5.81 \pm 1.36$ \\
\hline Packed cell volume $(\%)$ & 75 & $45 \pm 4$ \\
\hline Haemoglobin $(\mathrm{g} / \mathrm{l})$ & 52 & $173.2 \pm 29.9$ \\
\hline MCH $(\mathrm{pg})$ & 51 & $31.7 \pm 9.7$ \\
\hline MCV $(\mathrm{fl})$ & 75 & $79.8 \pm 19.2$ \\
\hline MCHC $(\mathrm{g} / \mathrm{l})$ & 47 & $389.2 \pm 66.4$ \\
\hline White blood cells $\left(\mathrm{x} 10^{3} / \mu \mathrm{l}\right)$ & 80 & $4.06 \pm 2.40$ \\
\hline Lymphocyte $\left(\mathrm{x} 10^{3} / \mu \mathrm{l}\right)$ & 77 & $2.87 \pm 1.94$ \\
\hline$(\%)$ & 77 & $68.5 \pm 16.7$ \\
\hline Heterophil $\left(\mathrm{x} 10^{3} / \mu \mathrm{l}\right)$ & 77 & $0.68 \pm 0.45$ \\
\hline$(\%)$ & 77 & $19.6 \pm 12.4$ \\
\hline Eosinophil $\left(\mathrm{x} 10^{3} / \mu \mathrm{l}\right)$ & 77 & $0.20 \pm 0.22$ \\
\hline$(\%)$ & 77 & $5.6 \pm 5.5$ \\
\hline Basophil $\left(\mathrm{x} 10^{3} / \mu \mathrm{l}\right)$ & 77 & $0.19 \pm 0.18$ \\
\hline$(\%)$ & 77 & $5.6 \pm 4.3$ \\
\hline Monocyte $\left(\mathrm{x} 10^{3} / \mu \mathrm{l}\right)$ & 77 & $0.04 \pm 0.06$ \\
\hline$(\%)$ & 77 & $1.0 \pm 1.2$ \\
\hline
\end{tabular}

Except for basophils in blood (either in relative or absolute count), no statistically significant difference between males and females was found. The males proved to have the percentage of $4.7 \pm 4.2 \%\left(0.15 \pm 0.12 \times 10^{3} / \mu \mathrm{l}\right)$ basophils that was significantly less (t-test, $p<0.05)$ than basophil count in females, which had $6.5 \pm 4.3 \%\left(0.24 \pm 0.22 \times 10^{3} / \mu \mathrm{l}\right)$ 
basophils. We observed no relationship between haematological indices and body weight. Anyway, there was observed an indirect proportion between birds' body weight and the percentage of basophils in blood. This applied to female group and the group of all birds irrespective of sex.

One great tit of all trapped birds was not in good health condition. It lost its leg, perhaps due to recent injury, and it was emaciated. The wound itself was already healed with no signs of inflammation. When collecting blood sample of this bird, we could withdraw only $30 \mu$. Therefore we did not determine the packed cell volume. The injured great tit had $2.87 \times 10^{6} / \mu \mathrm{l}$ red blood cells, $79.3 \mathrm{~g} / \mathrm{l}$ haemoglobin content in blood and $27.6 \mathrm{pg} \mathrm{MCH}$. Its total white blood cells were $22.9 \times 10^{3} / \mu 1$. In blood smears we distinguished $72 \%$ lymphocytes $(16.5 \times$ $\left.10^{3} / \mu \mathrm{l}\right), 25 \%$ heterophils $\left(5.7 \times 10^{3} / \mu \mathrm{l}\right)$ and $3 \%$ basophils $\left(0.7 \times 10^{3} / \mu \mathrm{l}\right)$. We found no eosinophils or monocytes.

Blood smears of healthy tits $(\mathrm{n}=77)$ indicated that 4 birds $(5.2 \%)$ had the blood parasites - three cases of Leucocytozoon (3.9\%) and one case of microfilariae (1.3\%). We distinguished no trypanosomes. The intensity of parasitic infection proved to be only 1 parasite per $10^{5}$ red blood cells in all cases. In blood smear of diseased tit we found blood parasites that were later identified as Leucocytozoon dubreuili (Mathis et Léger, 1911) (Plate XI, Fig. 1). Infection intensity was 28 parasites per $10^{5}$ red blood cells (1 parasite per 357 red blood cells).

\section{Discussion}

Except for packed cells volume, we found no literature about red blood count of the great tit. In comparison to other bird species, great tit showed a greater amount of red blood cells, higher haemoglobin content and larger packed cells volume - this is caused by the size of the bird and its intensive metabolism. Our overall red blood count results are most likely comparable to the results of budgerigar Melopsittacus undulatus (Harper and Lowe 1998) and to the values generally seen in passerines (Prinzinger and Misovic 1994). It is probably due to the similar size of great tit to the size of budgerigar and passerines. The packed cell volume we observed ( $45 \pm 4 \%$ ) was different from packed cell volume of great tits during their nesting period (54 $\pm 5 \%$ ) (Ots et al. 1998). So far, we cannot interpret the different packed cell volumes of great tits in winter and summer.

The total white blood cells in great tit $\left(4.01 \times 10^{3} / \mu \mathrm{l}\right)$ were even lower than in budgerigar. The percentage of white blood cells in great tit was similar to most of other avian species (Lucas and Jamroz 1961; Fudge 2000 etc.). In contrast to previously published studies (Dufva and Allander 1995; Ots et al. 1998), we observed more lymphocytes and fewer heterophils in great tit. These differences may be caused by birds' age, seasonal changes, feeding conditions or the daytime of blood taking. We assume that the seasonal changes had the dominant effect in our study as we examined great tits' blood in winter - in contrast to Dufva and Allander (1995) and Ots et al. (1998) who performed their examinations in the nesting period. It is questionable whether the increase in lymphocyte number and the decrease in heterophils number in winter correspond to great tits' adaptation to hostile clime or, conversely, whether the increase in heterophil number and the decrease in lymphocyte number in spring are caused by the stress on the organism due to reproductive processes. It is very difficult to determine the physiological values of haematological examination in wild birds because the results are influenced by many factors as above all overall health condition of birds or stress caused by trapping the birds, transient caging them and the blood taking itself (B o u n ou s 2000). Therefore it is necessary to handle the birds very carefully and take the blood as soon as possible after trapping. These conditions were fulfilled in our study. It is also known that haematological values depend on birds' age and sex, season and feeding (Maxwell 1987; Maxwell and Robertson 1998; Fudge 2000). 
Except for relative basophil count in blood, we observed no statistically significant difference between males and females. On the contrary, Ots et al. found out the differences in packed cells volume and heterophils count between great tit males and females but we were examining the birds in winter whereas Ots et al. (1998) in the nesting period. The variance of our results was perhaps caused by reduced sexual activity of birds in winter. Owing to different activities of males and females during the nesting period, females showed different requirements for tissue oxygen supply as compared to males. This was compensated by increased erythropoiesis (Hõrak et al. 1998). There is no dependence of physical activities on birds' sex in winter; therefore we found no differences in blood parameters. So far, we cannot explain why the female great tits had more basophils than the males. This phenomenon was described also in Japanese quail (Maxwell and Roberts on 1995; Pravda et al. 1996).

We observed no relationship between haematological parameters and body weight with the exception of relative basophil count. This was caused probably by the fact that body weight is not an optimal criterion for evaluation of health condition that influences blood count of adult birds. Statistically significant relationship between body weight and blood count parameters were found only in case of basophils percentage in blood smears. Increased number of basophils is often observed in birds that are in the initial stage of inflammatory disease, are hypersensitive, under long-term stress or have been given adrenocorticotropic hormone (ACTH) (Maxwell and Robertson 1995). We do not consider any of these circumstances to be a source of our results. Here we should remark that mean body weight of great tits examined in our study was at least by $1 \mathrm{~g}$ lower as compared to the results of Kožená (1983) who monitored body weight of great tits of the Czech Republic in winter. In her study, mean body weight of the males $(n=267)$ was $19.7 \mathrm{~g}$ while the females $(\mathrm{n}=$ 134) weighed $18.5 \mathrm{~g}$ on average.

In clinically healthy birds we found only $5.2 \%$ prevalence of blood parasites infection. Such a low rate of infected birds was caused by the fact that they were examined in winter when the incidence of vectors transmitting the infection was significantly reduced (Garvin et al. 1993). The infectious agents distinguished in the birds monitored in our study had probably entered their bodies during the previous year. The health condition of the birds got impaired. Members Leucocytozoon genus, as well as other blood parasites, are described in most wild birds as non-pathogenic while there are only a few mentions describing their possible pathogenicity (Bennett et al. 1993; Ots and Hõrak 1998; Merino et al. 2000).

We found normochromic, normocytic anaemia in one diseased great tit (with normal $\mathrm{MCH}$ and no polychromasia or anisocytosis in the smear). These parameters are usually observed in cases of non-regenerative anaemia that is quite common in birds and develops most often on chronic and inflammatory diseases (Fudge 2000). The condition of this great tit was probably caused by the injury resulting in the loss of its leg. As this bird was emaciated, we assumed that it was injured within relatively short period before the examination. Furthermore, the bird showed the signs of progressive inflammation, i.e. leucocytosis, lymphocytosis, heterophilia and mild basophilia. These changes were probably closely connected with the infestation of protozoal parasites Leucocytozoon dubreuili. This infection - that was very intensive in comparison to other monitored birds ( 1 leucocytozoon per 357 red blood cells) - became probably the cause of above-mentioned leucocytosis, lymphocytosis, heterophilia and basophilia.

The following species of Leucocytozoon genus were described in passerines: L. majoris Laveran, 1902, L. berestneffi Sambon, 1908, L. sakharoffi Sambon, 1908, L. fringillinarum Woodcock, 1910, L. dubreuili Mathis et Léger, 1911, L. maccluri Greiner, 1976 and L. balmorali Peirce, 1984 (Valkiũnas 1997). L. berestneffi species is described only in genera Pica and Cyanocitta. L. sakharoffi occurs only in Corvidae 
family. L. maccluri and L. balmorali species typically cause the oval and fusiform shape of affected cells. In case of $L$. majoris infection, the nucleus of affected oval cell has more or less constant width along all its length. In case of $L$. fringillinarum infection, the nucleus is shaped variously while encircling less than one half of gametocyte's circumference (Valkiũnas 1997).

As a matter of fact, $L$. dubreuili is a species morphologically best corresponding to our findings. The affected cells are typically oval; the nucleus is displaced into the affected cell periphery, becomes oblong while having its both ends enlarged and encircling more than one half of gametocyte circumference. Gametocyte sometimes fills the whole host cell but in most cases the remaining part of cytoplasm is visible. In the centre of gametocyte you can observe the nucleus and nucleolus, sometimes also vacuoles or pseudo-pigment granules (Valkiũnas 1997).

The most intensive incidence of blood parasites of above-mentioned genus is seen in the period of reproduction (Valkiũnas 1997). This might be caused by an extreme strain of songbirds' organism in this period and also by benign living conditions for black fly family (Simuliidae) that transmit the parasites (Shutler et al. 1999). Presumably, all these facts underlie the very low prevalence and intensity of infection that we observed in the healthy great tits.

\section{Hematologie a leukocytozoonóza u sýkor koňader (Parus major L.) v zimním období}

Dosud existuje jen málo prací částečně monitorujících krevní obraz u sýkory koňadry. Hematologicky bylo vyšetřeno 81 sýkor koňader (Parus major). Sýkory byly odchyceny v brněnském městském parku, Česká republika, v zimě 2000/2001. Vyšetřením 80 zdravých ptáků byly zjištěny tyto parametry: $5.89 \pm 1.36 \times 10^{6} / \mu 1$ erytrocytů, koncentrace hemoglobinu $173.2 \pm 29.9 \mathrm{~g} / \mathrm{l}$ a hematokrit $45 \pm 4 \%$, celkový počet leukocytů $4.06 \pm 2.40$ $\times 10^{3} / \mu$ l (68.5 \% lymfocytů, $19.6 \%$ heterofilů, $5.6 \%$ eosinofilů, $5.6 \%$ basofilů a $1.0 \%$ monocytů). V krvi jedné zraněné sýkory koňadry (úrazem amputovaná noha) byla zjištěna normochromní normocytární anémie a leukocytóza. Krevní nátěry byly vyšetřovány také na výskyt krevních parazitů (Leucocytozoon sp., Trypanosoma sp., mikrofilárie). U tří $(3.9 \%, n=77)$ zdravých ptáků byli nalezeni krevní paraziti rodu Leucocytozoon a v jednom případě $(1.3 \%, \mathrm{n}=77)$ také mikrofilárie (ve všech prŕípadech 1 parazit na $10^{5}$ erytrocytů). U úrazem hendikepované koňadry byla zjištěna infekce krevním parazitem Leucocytozoon dubreuili (intenzita infekce: 1 napadený erytrocyt na 357 nenapadených). Domníváme se, že $\mathrm{v}$ důsledku oslabení organismu traumatem došlo ke snížení obranyschopnosti této koňadry a k reaktivaci latentní infekce L. dubreuili.

\section{Acknowledgements}

We wish to thank Dr. Milena Svobodová from the Department of Parasitology, Charles University, Prague for her help with determination of Leucocytozoon dubreuili. The project was partly financed by Institute of Wildlife Ecology, Veterinary and Pharmaceutical University in Brno, and the Ministry of Education, Youth and Sports of the Czech Republic (project No. 161700 001).

\section{References}

BENNETT GF, PEIRCE MA, ASHFORD RW, 1999: Avian hematozoa: Mortality and pathogenicity. J Nat Hist 27: $993-1001$

BOUNOUS DI, WYATT RD, GIBBS PS, KILBURN JV, QUIST CF, 2000. Normal hematologic and serum biochemical reference intervals for juvenile wild turkeys. J Wildlife Dis 36: 393-396

CAMPBELL TW, 1994. Hematology. In Ritchie BW, Harrison GJ, Harrison LR. Avian Medicine: Principles and Application. Lake Worth: Wingers Publishing, Inc., pp. 176-198

DRABKIN DR, 1945. Crystallographic and optical properties of human hemoglobin. A proposal for the standartization of hemoglobin. Am J Med Sci 209: 268-270

DUFVA R, ALLANDER K, 1995. Intraspecific variation in plumage coloration reflects immune response in Great tit (Parus major) males. Funct Ecol 9: 785-789 
FUDGE AM, 2000. Laboratory Medicine: Avian and Exotic Pets. Philadelphia: W. B. Saunders Company, 482 p. GARVIN MC, REMSEN JV, BISHOP MA, BENNETT GF, 1993. Hematozoa from passeriform birds in Louisiana. J Parasitol 79: 318-321

HARPER EJ, LOWE B, 1998. Hematology values in a colony of budgerigars (Melopsittacus undulatus) and changes associated with aging. J Nutr 128: $2639-2640$

HÕRAK P, OTS I, MURUMÄGI A, 1998. Haematological health state indices of reproducing Great tits: a response to brood size manipulation. Funct Ecol 12: 750-756

KOŽENÁ I, 1983. Parus major Linnaeus, 1758 - sýkora koňadra, rozměry (in Czech). In: Hudec K, (Ed.): Fauna ČSSR, Ptáci - Aves III/2. Praha, Academia, pp. 791

LUCAS AM, JAMROZ C, 1961. Atlas of Avian Hematology. Washington, United States Department of Agriculture, Agriculture Monograph 25, $271 \mathrm{p}$

MAXWELL MH, ROBERTSON GW, 1995. The avian basophilic leucocyte: a review. World Poultry Sci J 51: 307-325

MAXWELL MH, ROBERTSON GW, 1998. The avian heterophil leucocyte: a review. World Poultry Sci J 54: $155-78$

MAXWELL MH, 1987. The avian eosinophil - A review. World Poultry Sci J 43: 190-207

MERINO S, MORENO J, SANZ JJ, ARRIERO E, 2000. Are avian blood parasites pathogenic in the wild? A medication experiment in Blue tits (Parus caeruleus). Proc R Soc Lond B 267: 2507-2510

MERINO S, POTTI J, FARGALLO JA, 1997. Blood parasites of passerine birds from central Spain. J Wildlife Dis 33: 638-641

NATT MP, HERRICK CA, 1952. A new blood diluent for counting the erytrocytes and leucocytes of the chicken. Poultry Sci. 3: $735-738$

OTS I, HÕRAK P, 1998. Health impact of blood parasites in breeding great tits. Oecologia 116: 441-448

OTS I, MURUMÄGI A, HÕRAK P, 1998. Haematological health state indices of reproducing Great tits: Methodology and sources of natural variation. Funct Ecol 12: 700-707

PRAVDA D, BOĎA K, BAUMGARTNER J, JELÍNEK P, KUČÍNSKÝ P, OKRUHLICA M, PETROVSKÁ E 1996. Haematological parameters of Japanese quail (Coturnix coturnix japonica) kept in cages under normal conditions and exposed to long-time experimental hypodynamy. Acta Vet Brno 65: 93-97

PRINZINGER R, MISOVIC A, 1994. Vogelblut - eine allometrische Übersicht der Bestandteile. J Ornithol 135:133-165

SHUTLER D, ANKNEY CD, MULLIE A, 1999. Effects of the blood parasite Leucocytozoon simondi in growth rates of anatid ducklings. Can J Zool 77: 1573-1578

VALKIŨNAS G, 1997. Bird haemosporida (in Russian). Acta Zool Lituanica 3-5: a monograph, Vilnius: Institut of Ecology, 608 p. 
Plate XI

Hauptmanová K. et al.: Haematology... pp. 199-204

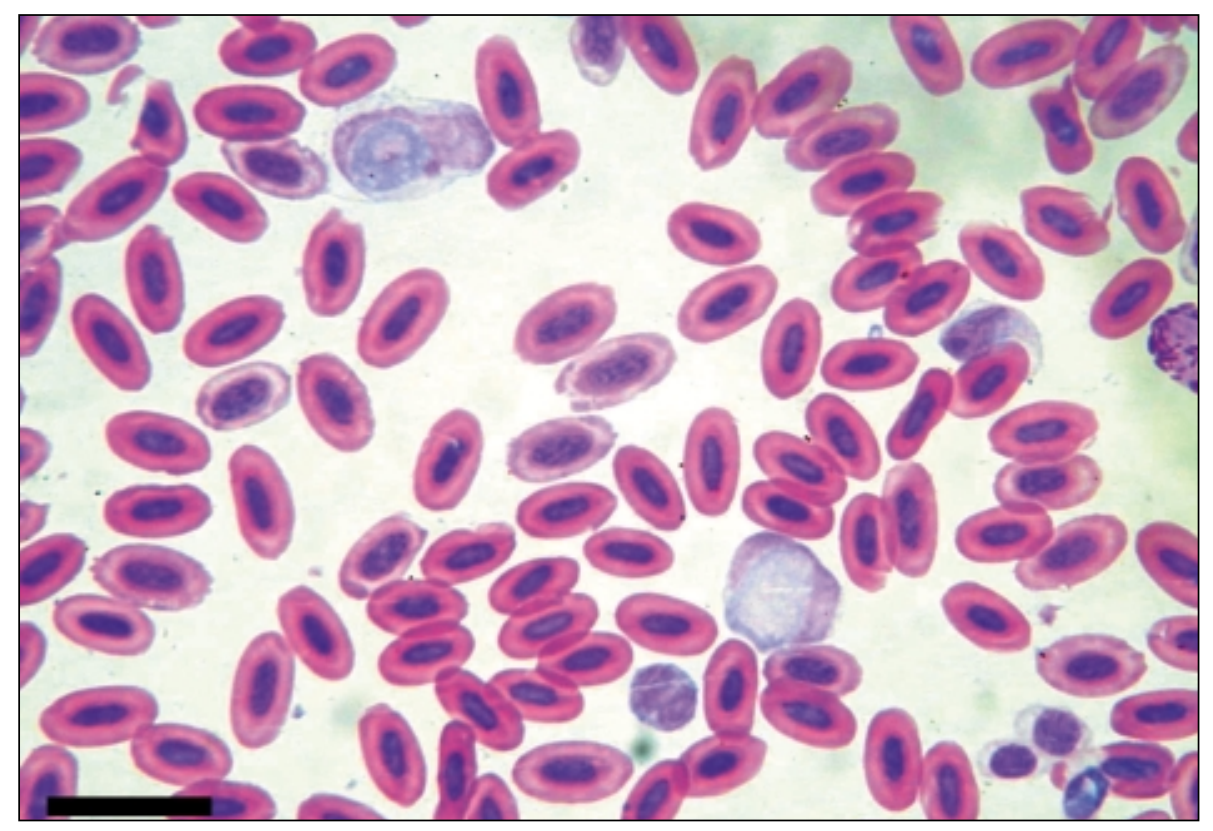

Fig. 1. Leucocytozoon dubreuili in blood smear of diseased great tit. Bar $=20 \mu \mathrm{m}$. 